would be of the order of the difference of specific heat as determined with a single crystal and with the same mass of small crystals.

\section{Spectroscopic Data}

Whereas the Debye and Born theories lead to vibration frequencies of a crystalline solid giving a continuous spectrum, the Raman theory leads to a line spectrum. The relevant experimental data may be got from studies of the Raman spectra, the luminescence of crystals excited by light or by electric bombardment, and the absorption spectra.

A striking feature of the spectrum of the radiation scattered when a monochromatic beam traverses a transparent crystal is the sharpness of the lines of displaced frequency appearing in the infra-red. This feature is characteristic of the lines associated with either extensional or distortional vibrations of the ions or molecules in the crystal lattice or with translational or rotational motions. The latter type fails to appear when the substance is in the amorphous or fluid state, being then replaced by a diffuse continuum. The monochromatism of the vibrations is therefore closely associated with the crystalline state. Two plates are reproduced showing this monochromatism associated with superlattice frequencies for quartz and diamond.

Detailed studies of the relevant data have been made in the. Physics Department of the Indian Institute of Science, Bangalore, and are presented in a series of six papers. R. Norris deals with white phosphorus and quartz, B. Dayal with the cubic metals (lithium, tungsten, gold, silicon and grey tin) and with the hexagonal metals (magnesium, zinc and cadmium), V. B. Anand deals with diamond and C. S. Venkateswaran with alkali halides. Good or improved agreement of theory with experiment is found by using the Raman theory instead of the Debye theory. Numerical comparisons using the Born theory appear to be missing. The bulk of the thermal energy is associated with unit-cell frequencies appearing as monochromatic lines in the infra-red. The residue, associated with superlattice frequencies, appears in the remote infra-red, is monochromatic and is relatively important only at low temperatures.

\section{ADVANCE IN INVENTION: ITS RELATION TO WORLD PEACE}

\section{BY D. CARADOG JONES \\ University of Liverpool}

A YEAR after the outbreak of the present War the results were published of a study of the causes of the failure to preserve peace. The members of the study group are described as mainly officers of international organizations with headquarters at Geneva, meeting unofficially and able therefore to contribute to the discussion without reserve. The publication was issued under the authority of the Carnegie Endowment for International Peace.

\section{World Unity}

The factors that led to war are classed under three heads : political, economic, spiritual. But all three, when critically examined, are revealed as a failure to visualize the world as an organic whole. "The most startling example of the collective failure" to take a world view, under the political head, they say "was the attitude adopted toward Germany, not only in the clauses of the settlement, but still more in the manner of their presentation. . . . In particular, the refusal to negotiate with Germany created an attitude of mind in that country that was never subsequently changed." Put the rulers of Germany under restraint ; yes. Make the German people suffer; impossible, unless we are prepared ourselves to suffer with them. However much they may appear to our limited vision to deserve punishment, by placing them in the dock we shall but bring judgment upon our own heads. We are reminded of an illuminating analogy due to that far-sighted statesman, Señor S. de Madariaga: "A nation, a limb of the world, misbehaves, i.e., it acts against the world community, which is the whole body. And sanctions are decided on to punish it. But, can we punish a limb without punishing the whole body ?" If we sow the wind, we reap the whirlwind.

The fundamental character of this principle of world unity comes out nowhere so clearly as in the economic aspect of international relations. The Geneva group recall the sequence of events following the attempt to extract huge reparations from Germany. Failure to grasp the fact that payment in goods would immediately put large numbers of people in the allied countries out of work may be taken as evidence that the mismanagement of affairs after the War of 1914-18 was due in large measure to a lack of understanding of elementary economics. It was as much a failure of the head as of the heart. Happily there are signs of greater enlightenment among those who are at present responsible for advising the leaders of the democratic Governments in such matters. In particular, they are fully aware of the consequences of the remarkable progress achieved in technological invention. This was causing so great a revolution in industrial production, even before 1914 , that it was bound sooner or later to lead to trouble between nations if each attempted to pursue its own selfinterested path regardless of the welfare of others; and this new industrial revolution may cause still greater disaster after the present War if its implications are not more widely and clearly realized. It is essential that Governments should be able to depend upon the support of public opinion for any concerted measures they may adopt for the control of output and its distribution, in the interests of the world as a whole and especially of the weaker nations.

\section{Progress in Output}

A few facts may be given which bear striking witness to the extent and the rate of advance in the output capacity of modern machinery. Colin Clark has made a comparison of the real income produced per head of the working population in different countries on the basis of a 48-hour week. His figures indicate a rise in Sweden and Japan to a level more than four times as high as that reached seventy or eighty years ago. In most highly industrialized countries the income so calculated has been at least doubled during the same period of years, and this was accomplished in spite of a considerable increase in population and decrease in the hours of work. In the last two decades the rate of progress has been even more astonishing. According to an estimate published by the Royal Economic Society, the increase in physical output per operative in the United 
Kingdom, for all industries covered by the Board of Trade Census of Production, was 34 per cent between the years 1924 and 1935 and 27 per cent during 19301935. For engineering the corresponding increase, 1830-1935, was 57 per cent ; for textiles, 37 per cent. Even allowing a considerable margin of error in all these figures, there is not the least doubt about their general trend. Moreover, the wide range of invention is as striking as the acceleration in output. The telephone, the motor-car, the aeroplane, the motion picture, and radio have had so far-reaching an influence upon the structure of society-turning almost unknown nations into next-door neighbours overnight--that it is only with a jerk of memory we recall that they are largely the product of the present century. About a million telephones were in use and the motor-car was just being introduced into the United States forty years ago; now the telephone industry is the third largest public utility concern in the country and there is one motor-car for every five people. The aeroplane was regarded with scepticism and the other two inventions were as yet unknown. These facts are mentioned by Prof. W. F. Ogburn in a recent American publication, which directs attention also to the immense and fascinating possibilities the future holds for us, arising out of the discovery of synthetic resins and plástics; rayon, artificial cotton, and wool derived from cellulose; synthetic rubber and wood substitutes ; devices such as the photo-electric cell, and many other inventions.

What does all this imply? It should surely imply a fuller and more varied life for all mankind, if only we could agree upon a fair method of sharing the products of hand and brain. There comes the hitch. The new industrial revolution burst upon us unprepared; we all know how a few primary producers were driven in sheer desperation to destroy their surplus stock, after a vain attempt to dispose of the overwhelming output of certain commodities at remunerative prices. Is there no danger that the same conditions will return. when this War ends? The urgency of essential war requirements speeds up output enormously and sharpens inventive wit. It is certain, therefore, that the pace and capacity of production of our machines will be very much greater than they were when the War of 1914-18 ceased. Past experience proves, too, that it will be a relatively simple matter to change over from war to peace production. Yet, before this War started, it was estimated that the people of the United States, to take but one example, could subsist if necessary on about one third of their output, leaving the remaining two thirds to be devoted to other purposes. What is true of the United States is true, in varying degrees, of other equally advanced countries.

\section{Problem of Surpluses}

This presents the problem of surpluses in a new and significant light. It is clear that under conditions of peace, if our aim is to provide employment for all who are capable of work-since sharing the work available, by a general reduction in the weekly hours of labour, would only be a partial solution of the unemployment problem-the potential supply of many commodities, with full employment, will far exceed the effective demand for them within the country of their origin. What then can the United States, for example, do with her vast surplus? She can only hope to exchange a relatively small part of it for the few commodities which she cannot herself produce. As for the rest, she has a choice of four courses: she can destroy it, which no one would commend; she can store it or sell it on long credit, but either of these two courses would only put off the day of reckoning and make the problem more difficult to solve eventually; the one choice left open is to give it away to nations whose need is greater than her own. To put this last suggestion into practice, though at first sight revolutionary, would be entirely consistent with the fundamental principle of world unity, whereby all the peoples of the world are regarded as one people, one family of nations. The average real income per occupied person in the United States has been very roughly estimated at one hundred dollars a month; the corresponding figure in India or China would be equivalent to five or ten dollars at most. There is a like discrepancy between the standard of living among these Asiatic peoples and that which we in Great Britain enjoy, and the difference is a measure of our responsibility towards them. A carefully planned scheme of assistance, covering all aspects of life, would in course of time result in greatly improved conditions in both India and China.

How is such assistance to be given ? Let us suppose that, with the return of peace, a time comes when we have in use all the labour we can effectively employ to satisfy our own needs, but that many men are still without work and our machines are not running at full pressure. Manufacturers are unwilling to take the risk of increasing their production, because they anticipate no increase in demand in the home or foreign market at existing prices. There are two courses then open. The Government may maintain these potential workers in idleness, which is bad for everybody, concerned. That was the policy adopted after 1914-18. The alternative is to find work for them. India and China are in sore need of tractors and other agricultural implements. They might indeed be able and willing to pay for them with rice, tea, silk and other commodities if the price asked were not too high. But it would be far better for the British Government to make free gifts to these countries than to permit our labour force and our plant to deteriorate by remaining idle. The cost of the creation of any additional credit notes needed would be trifling, and no money is wasted, in the sense of being used up, by circulating it. Contracts would be given to engineering firms in the normal way ; they would be paid fair prices and the workmen would receive good wages for the work done. Their increased earnings would result in increased expenditure, bringing extra gain to shopkeepers and others, besides extra revenue to the Government in taxation. It is thus evident that, by helping to raise the standard of living of depressed peoples, our own standard would rise simultaneously. No nation can move forward at the expense of others : we can only advance togetheryet another illustration of the organic unity of the world.

\section{International Pool Control}

It should be a relatively simple matter, therefore, to accumulate a pool of surpluses of many kinds from Great Britain, the United States and other advanced countries. This pool might be placed under the control of an International Advisory Council, composed of experienced men and women of the highest integrity, capable of taking a world view in the handling of the delicate problems arising between nations. Such a Council, assisted by fact-finding Commissions 
of economic and other specialists, would command high authority. It would express a reasoned opinion for the guidance of Governments as to the wisest and most just plan for the control of world production and the disposal of surpluses, based upon a judicial and expert examination of all the data available. The relatively rich countries could be credited if they so wished, at agreed nominal prices, with any 'gifts' they contributed to the pool, and these credits would be regarded as giving them a call upon the pool at any future time should they themselves be in need.

It is not too soon to consider the setting up of an Advisory Council now. The judges of the Permanent Court of International Justice, seeing that they have established for themselves a reputation for wisdom and impartiality, might be invited to prepare a scheme for the selection of a panel of suitable people to serve upon it. Plans are already under discussion for the feeding and restoration of the famine-stricken inhabitants of European countries. It is too big a task for ourselves and America alone; all countries should take pride in working together for this purpose. It might well be handed over to such a body as the proposed Advisory Council. The disposal of surpluses and the feeding of the hungry are clearly complementary problems : the solution of the first is the key to the solution of the second.

One fundamental difference is to be noted between this approach to post-war problems and the Conference method adopted after the War of 1914-18. We leave the arena of politics, where each nation has its own ends in view, and become intent upon an objective and scientific task: seeking to satisfy, out of our common store, the elemental needs of all peoples. Upon that sound moral and psychological basis it should be possible to go on to build a peaceful World Order.

\section{METEOROLOGICAL RESEARCH IN GREAT BRITAIN}

\section{AIR MINISTRY RESEARCH COMMITTEE}

$\mathrm{T}$ HE importance of meteorology to aviation has necessitated an extension of the State meteorological service far beyond the modest dreams of meteorologists of the last generation. At the present time meteorological forecasting is a vital element in the national war effort, especially in the conduct of the offensive; but the return of peace and the renewed expansion of civil aviation will maintain the need for weather prediction, which also has great importance for agriculture and many other branches of the national economy.

The science and art of weather prediction have made great progress during the present century, but it remains uncertain whether even now all the fundamental factors that determine the weather changes have been discovered, and also whether the programme of observation yet includes all the elements necessary as a foundation for prediction. The problems both of observation and of theory are extremely complicated. It is therefore desirable that, along with the day-to-day application of the knowledge already available, proportionate efforts should be made to improve our knowledge and our methods.

For this reason the Secretary of State for Air has recently appointed a Meteorological Research Committee to advise and assist in the carrying out of meteorological investigations. The Committee is constituted as follows: Prof. S. Chapman, professor of mathematics at the Imperial College of Science and Technology (chairman); Prof. D. Brunt, professor of meteorology at the Imperial College of Science and Technology; Dr. G. M. B. Dobson, reader in meteorology in the University of Oxford; Prof. G. I. Taylor, Yarrow research professor of the Royal Society; the Director of the Meteorological Office; the Director of Scientific Research of the Ministry of Aircraft Production; the Director of the Naval Meteorological Service; and representatives of the Air Staff and civil aviation.

At present the Committee will naturally be concerned chiefly with problems directly concerned with the war effort, and such work must for the time being remain secret, though any incidental results not likely to be of service to the enemy may be published.

The Committee would welcome contact and cooperation with university departments or other institutions engaged on work that bears on meteorology ; as a result of inquiries in the United Kingdom, information concerning such work, and offers of assistance, have been received from several universities. Correspondence, which should be addressed to the Secretary; Meteorological Research Committee, Meteorological Office, Air Ministry, Kingsway, London, W.C.2, is invited from any other university or research institutions which can assist in this work.

\section{Co-operation of the Royal Society}

The formation of a Meteorological Research Committee by the Air Ministry, announced above, is an important and very welcome advance in the organization of British meteorological research. The Air Ministry Committee will at present confine its work chiefly to those problems which have an immediate practical application and are likely to be solved in a fairly short time. The Royal Society has been invited by the Air Ministry to co-operate with the Meteor. ological Research Committee by undertaking research on certain aspects of meteorology which, though of fundamental importance for the advance of the subject, may not have an immediate practical application.

The Council of the Royal Society has agreed to this request, and has entrusted the immediate responsibility for the work to the Gassiot Committee. This Committee, first constituted in 1871, was originally appointed to administer the Gassiot and other trust funds applicable to the maintenance of certain British meteorological and magnetic observatories, and to make recommendations as to their work. The terms of reference have now been enlarged to include the supervision of fundamental meteorological research such as has been asked for by the Air Ministry. The personnel of the Committee is appropriate for this purpose; the chairman is Dr. G. M. B. Dobson, and the members are Sir Edward Appleton, Profs. D. Brunt and S. Chapman, Sir Henry Lyons, Sir George Simpson, Prof. G. I. Taylor, Sir Gilbert Walker, the Astronomer Royal, the President of the Royal Astronomical Society, the Director of the Meteorological Office, and ex officio, the Treasurer of the Royal Society (Prof. T. R. Merton) and the Secretary of the Royal Society (Prof. A. C. G. Egerton).

These arrangements seem eminently suitable, because pure fundamental research which may have 